\title{
Increasing Access to Specialized Dermatology Care: A Retrospective Study Investigating Clinical Operation and Impact of a University-Affiliated Free Clinic
}

Thomas Hester - Reinie Thomas · Jean Cederna · Ann Marie Peterson •

Julie Brown · Timothy M. Johnson · Kelly B. Cha (D)

Received: September 24, 2020 / Published online: November 11, 2020

(C) The Author(s) 2020

\section{ABSTRACT}

Introduction: Our objective was to study the impact and clinical operation of an integrated model for free specialized dermatology care via collaboration between an academic institution and a nonprofit outpatient clinic through an analysis of patient demographics and care provided.

Methods: Hope@UMHS is a partnership between the University of Michigan Health System (UMHS) and Hope Clinic (HC) which provides free specialty consultations to uninsured residents of Southeast Michigan. A retrospective chart review was completed for

T. Hester · R. Thomas - T. M. Johnson ·

K. B. Cha $(\varangle)$

Department of Dermatology, University of

Michigan, Ann Arbor, MI, USA

e-mail: kellycha@med.umich.edu

J. Cederna · A. M. Peterson · J. Brown

Hope Clinic, Ypsilanti, MI, USA

T. M. Johnson

Ganger Dermatology, Ann Arbor, MI, USA patients referred to the UMHS Dermatology clinic as part of the HOPE@UMHS collaboration from April 2012 through February 2020.

Results: Of the 294 referred patients, 264 were managed in 30 clinic sessions over 8 years, staffed by 92 unique volunteers. Patients most commonly presented with atopic dermatitis $(10.5 \%)$, seborrheic dermatitis (7.9\%), and actinic keratosis $(7.4 \%)$. The majority of patients $(68.2 \%)$ were prescribed at least one new medication. Nine skin cancers, including one melanoma, were diagnosed and treated. There were 102 procedures performed. Eighty-seven percent of patients received conclusive evaluation and treatment at the time of their consultation. Conclusion: Our experience illustrates that providing free, comprehensive dermatology care in a university hospital by partnering with a nonprofit clinic is both feasible and beneficial to the greater community.

Keywords: Charity care; Free clinic; Free dermatology clinic; Free specialty care; Safety net 


\section{Key Summary Points}

Indigent patients have limited access to specialized dermatology care.

We retrospectively review a collaboration between an academic center and a community health center, providing free dermatology care in southeast Michigan over an 8-year period, to describe patient characteristics, diagnoses, management plans, and volunteerism.

Our collaboration may serve as a model for providing dermatology care to underserved patients and important volunteer and learning opportunities to physicians, staff, and students.

\section{DIGITAL FEATURES}

This article is published with digital features, including a summary slide, to facilitate understanding of the article. To view digital features for this article go to https://doi.org/10.6084/ m9.figshare.13118012.

\section{INTRODUCTION}

The US healthcare system provides uninsured patients with only limited access to healthcare $[1,2]$. Individuals without insurance experience delays when seeking care, present with more advanced disease, and experience worse clinical outcomes than their insured counterparts [1]. To address this gap in care, free "safety net" clinics deliver services at minimal to no cost through community support, government funding, and volunteers $[5,6]$. In the state of Michigan (MI), there are currently 56 free clinics available to serve the state's uninsured patients, which numbered 535,000 in 2018 $[7,8]$.

Uninsured patients have particular difficulty in accessing specialty care, including

dermatology [9]. Over $40 \%$ of US citizens live in areas underserved by dermatologists $[12,13]$. This disparity is further pronounced among indigent patients, as nearly half of all dermatologists may not evaluate and treat uninsured patients or those with Medicaid $[10,14]$. When Medicaid enrollees do receive care for skin conditions, the care is less likely to be from a dermatologist [10]. These gaps in care have ramifications, as dermatology consultations alter care significantly, improving management and outcomes in conditions ranging from acne to cellulitis to melanoma [15]. Factors such as race and insurance status have been associated with differences in mortality for melanoma and mycosis fungoides [21]. In order to improve outcomes among the uninsured in the USA, we must first improve their access to care.

Of the 56 free clinics in Michigan, only four or five provide specialty dermatology services (Ann Heler, President of the Free Clinics of Michigan, personal communication, with permission; 18 August 2020) [5]. The Hope Clinic (HC) (https://www.thehopeclinic. org) is a nonprofit entity located at two sites (Ypsilanti and Westland, MI) that offers free medical and social services to low-income and uninsured patients in the surrounding area. Serving more than 5000 clients annually, the clinic operates through the financial support of individuals, corporations, and foundations in conjunction with over 50,000 volunteer hours donated yearly. Services provided include medical, dental, and mental health, social services, food and laundry services, and prayer. In 2019, 1306 unique patients presented for medical care. HC has expanded its on-site primary care services to include off-site specialty consultations through a partnership with the University of Michigan Health System (UMHS), headquartered in Ann Arbor, MI, adjacent to Ypsilanti. UMHS Dermatology joined this collaboration, termed Hope@UMHS, in 2012.

Our objective was to analyze a retrospective dataset to study the impact and clinical operation of an integrated model for providing free specialized dermatology care within an 
academic institution in partnership with a nonprofit community clinic.

\section{METHODS}

\section{Collaboration}

The Hope@UMHS collaboration began with otolaryngology services in $2010[25,26]$ and expanded to include multiple other subspecialties, incorporating dermatology consultations in 2012. A Memorandum of Understanding was written and signed by UMHS and HC under the counsel of legal, risk management, senior administration, and facilities management. UMHS volunteers rendering professional services are eligible for medical malpractice coverage under the UMHS coverage program. Volunteers function within the limits of their licensure or under delegated authority with all necessary supervision required by law. A space or "rental" agreement is signed by a HC administrator each year. Patients referred from HC to UMHS Dermatology remain HC patients, and all subsequent care is coordinated through the greater HC infrastructure.

\section{Scheduling and Logistics}

Uninsured patients referred to Hope@UMHS Dermatology from HC primary care providers are scheduled for a quarterly Saturday morning clinic at the UMHS outpatient dermatology facility. HC maintains a list of dermatology referrals, contacts, and schedules, and reminds patients of their appointments. Patients are mailed appointment confirmations and receive a phone call reminder 3 days prior to the clinic visit. Those who miss and do not respond to calls over the course of two specialty appointments lose their specialty referral. Patients are given parking vouchers by UMHS and assisted in transportation needs by HC. Both Hope Clinics and the UMHS specialty clinics are accessible via public transportation.

\section{Staffing}

Clinics are staffed by volunteer UMHS dermatology employees. Clinic volume is dependent on HC referrals, typically capped at 12 patients per clinic session, and volunteers are recruited according to patient census. Each clinic ideally has a minimum of five volunteers: one at the front desk, one to two medical assistants, one to two medical students, one to four dermatology residents or physician's assistants, and one to two attending physicians. Volunteers are recruited approximately 3-4 weeks prior to clinic to ensure appropriate personnel.

\section{Scope of Practice}

New patients may be referred for any dermatology concern beyond the comfort level of their primary provider. The clinic operates in the typical US dermatology setting, and patients receive on-site biopsies and procedures, including tangential and punch biopsy, potassium hydroxide $(\mathrm{KOH})$ and mineral oil preparations, cryotherapy, intralesional triamcinolone injection (ILK), and electrodesiccation and curettage (ED\&C). Patients may also be referred on the same day or on future clinic dates to other subspecialty services involved in the Hope@UMHS collaboration, including plastic surgery and otolaryngology, which provide care in close proximity to the dermatology clinic. Patients who require excision are referred to plastic surgery. All related costs are absorbed by UMHS. Dermatopathologic expertise is provided by another institution collaborating with HC. An online pharmaceutical coupon resource (GoodRx) is used to determine the most affordable, logistically feasible plan for obtaining any prescriptions at commercial pharmacies. In accordance with UMHS institutional policy, medication samples are not provided to Hope@UMHS patients, but occasionally HC has some basic medications available on-site for patient use. HC support staff communicate after the clinic with patients who need prescriptions to support compliance. Interpreter services are provided by phone or family members. Followup is primarily handled by HC providers, who 
have open communication with UMHS providers for any patient questions or concerns that arise. Patients who require ongoing or additional specialty care are provided counseling services by HC to obtain insurance or charity care, such as through the University of Michigan's MSupport program; in rare cases in which dermatology follow-up is required and cannot be obtained otherwise, return visits are available.

\section{Documentation}

The HC prepares patient charts for each clinic and houses patient care records permanently in its facility. Dermatology consultants complete a paper record of the visit for HC documentation.

\section{Data Analysis}

A retrospective chart review was completed for patients referred and scheduled for a visit to the UMHS Dermatology clinic as part of the HOPE@UMHS collaboration from 21 April 2012 through to 29 February 2020. Data from 30 clinic sessions were analyzed. Availability of demographic data was limited and variable due to patients' ability to opt out of self-reporting. Two clinics (in which 17 patients were evaluated) were excluded from the diagnosis and management analysis due to insufficient records. Level of service was determined by dermatology consultants; corresponding Current Procedural Terminology (CPT) codes were assigned to each patient encounter.

The study was deemed exempt research by the University of Michigan Institutional Review Board (IRB) (Study eResearch ID: HUM00182333; date of IRB exempt determination: 19 May 2020).

\section{RESULTS}

From April 2012 through February 2020, 30 dermatology clinic sessions were held. A total of 294 patients were referred and scheduled for consultation; of these, ten cancelled after the appointment was scheduled, and 246 were
Table 1 Patient characteristics

\begin{tabular}{|c|c|}
\hline Patient characteristics & $N$ (\% respondents) \\
\hline \multicolumn{2}{|l|}{$\operatorname{Sex}(N=208)$} \\
\hline Male & $99(47.6)$ \\
\hline Female & $109(52.4)$ \\
\hline \multicolumn{2}{|c|}{ Age distribution (years) $(N=204)$} \\
\hline $10-18$ & $6(2.9)$ \\
\hline $19-64$ & $174(85.3)$ \\
\hline$>65$ & $24(11.8)$ \\
\hline \multicolumn{2}{|l|}{ Ethnicity $(N=187)$} \\
\hline White (non-Hispanic) & $98(52.4)$ \\
\hline Black/African & $38(20.3)$ \\
\hline Asian & $29(15.5)$ \\
\hline Hispanic/Latino & $18(9.6)$ \\
\hline Other & $4(2.1)$ \\
\hline \multicolumn{2}{|c|}{ Primary language $(N=182)$} \\
\hline English & $121(66.5)$ \\
\hline Albanian & $24(13.2)$ \\
\hline Spanish & $11(6.0)$ \\
\hline Chinese & $5(2.7)$ \\
\hline Other (12 languages) & $21(11.5)$ \\
\hline \multicolumn{2}{|l|}{ Citizenship $(N=176)$} \\
\hline US Citizen & $107(60.8)$ \\
\hline Permanent US resident & $45(25.6)$ \\
\hline Visitor & $24(13.6)$ \\
\hline \multicolumn{2}{|c|}{ Reason for referral $(N=220)$} \\
\hline Rash & $125(56.8)$ \\
\hline Lesion & $77(35.0)$ \\
\hline Hair/nails & $18(8.2)$ \\
\hline Total referrals & $294(100.0)$ \\
\hline Cancellation & $10(3.4)$ \\
\hline No show & $38(12.9)$ \\
\hline Total patient encounters & $246(83.7)$ \\
\hline
\end{tabular}


Table 2 Dermatologic diagnoses

\begin{tabular}{|c|c|}
\hline Diagnosis & $N$ (\% patients) \\
\hline Dermatitis & $51(22.3)$ \\
\hline Atopic & $24(10.5)$ \\
\hline Contact & $4(1.7)$ \\
\hline Stasis & $4(1.7)$ \\
\hline Nummular & $2(0.9)$ \\
\hline Unspecified & $17(7.4)$ \\
\hline Nevi & $22(9.6)$ \\
\hline Atypical & $13(5.7)$ \\
\hline Benign & $9(3.9)$ \\
\hline Wart & $22(9.6)$ \\
\hline Genital & $9(3.9)$ \\
\hline Plantar & $2(0.9)$ \\
\hline Unspecified & $11(4.9)$ \\
\hline Seborrheic dermatitis & $18(7.9)$ \\
\hline Actinic keratosis & $17(7.4)$ \\
\hline Acne & $16(7.0)$ \\
\hline Tinea & $16(7.0)$ \\
\hline Pedis & $9(3.9)$ \\
\hline Onychomycosis & $3(1.3)$ \\
\hline Manus & $2(0.9)$ \\
\hline Capitis & $1(0.4)$ \\
\hline Corporis & $1(0.4)$ \\
\hline Alopecia & $16(7.0)$ \\
\hline Androgenetic & $3(1.3)$ \\
\hline Telogen effluvium & $3(1.3)$ \\
\hline Areata & $2(0.9)$ \\
\hline Dissecting cellulitis & $1(0.4)$ \\
\hline Lichen planopilaris & $1(0.4)$ \\
\hline Unspecified & $6(2.6)$ \\
\hline Seborrheic keratosis & $15(6.6)$ \\
\hline Folliculitis & $13(5.7)$ \\
\hline Psoriasis & $12(5.2)$ \\
\hline Pigmentary change & $11(4.8)$ \\
\hline
\end{tabular}

Table 2 continued

\begin{tabular}{|c|c|}
\hline Diagnosis & $N$ (\% patients) \\
\hline $\mathrm{PIH}$ & $4(1.7)$ \\
\hline Vitiligo & $3(1.3)$ \\
\hline Melasma & $2(0.9)$ \\
\hline Hyperpigmented patches & $1(0.4)$ \\
\hline Dyspigmentation & $1(0.4)$ \\
\hline Rash (unspecified) & $10(4.4)$ \\
\hline Xerosis & $10(4.4)$ \\
\hline Skin cancer & $9(3.9)$ \\
\hline $\mathrm{BCC}$ & $7(3.1)$ \\
\hline Melanoma & $1(0.4)$ \\
\hline Bowenoid papulosis & $1(0.4)$ \\
\hline Cyst & $9(3.9)$ \\
\hline Epidermoid & $5(2.2)$ \\
\hline Pilar & $1(0.4)$ \\
\hline Unspecified & $3(1.3)$ \\
\hline Keloid/hypertrophic scar & $7(3.1)$ \\
\hline Other infections & $7(3.1)$ \\
\hline HSV & $2(0.9)$ \\
\hline Molluscum & $1(0.4)$ \\
\hline Impetigo & $1(0.4)$ \\
\hline Tinea versicolor & $1(0.4)$ \\
\hline Pityriasis rosea & $1(0.4)$ \\
\hline Scabies & $1(0.4)$ \\
\hline Vascular & $6(2.6)$ \\
\hline Angioma & $4(1.7)$ \\
\hline Stork patch & $1(0.4)$ \\
\hline Hemangioma & $1(0.4)$ \\
\hline Lichen simplex chronicus & $6(2.6)$ \\
\hline Rosacea & $6(2.6)$ \\
\hline Hidradentitis Suppurativa & $5(2.2)$ \\
\hline Intertrigo & $5(2.2)$ \\
\hline Photodamage & $5(2.2)$ \\
\hline
\end{tabular}


Table 2 continued

\begin{tabular}{ll}
\hline Diagnosis & $\boldsymbol{N}$ (\% patients) \\
\hline Skin tag & $5(2.2)$ \\
Connective tissue disease & $4(1.7)$ \\
DM & $2(0.9)$ \\
DM v. SLE & $1(0.4)$ \\
CREST & $1(0.4)$ \\
Dermatofibroma & $4(1.7)$ \\
Lichen planus & $3(1.3)$ \\
Other less common & $37(16.1)$ \\
\hline
\end{tabular}

BCC Basal cell carcinoma, CREST calcinosis, raynaud phenomenom, esophageal dysmotility, sclerodactyly, telangiectasia, $D M$ dermatomyositis, $H S V$ Herpes Simplex Virus, $P I H$ post-inflammatory hyperpigmentation, SLE systemic lupus erythematosus,

evaluated in clinic, averaging 8.2 patients per session. The no-show rate was $13.4 \%$. Patient characteristics and demographics are listed in Table 1. In total, 367 dermatologic diagnoses were noted in 229 patient records from data obtained from the 28 clinics available for this analysis (Table 2). The average patient had 1.6 diagnoses identified. Management strategies are outlined in Table 3. The majority of patients (68.2\%) were prescribed at least one new medication, with the most common recommendation being topical steroid (31.0\%). There were a total of 102 procedures performed, of which $47.1 \%$ were diagnostic (biopsy, $\mathrm{KOH}$ ) and $52.9 \%$ were therapeutic (cryotherapy, ILK, $\mathrm{ED} \& \mathrm{C})$.

Skin cancer was detected in nine patients. Seven were diagnosed with basal cell carcinoma, treated with excision or ED\&C through Hope@UMHS. One case of bowenoid papulosis was diagnosed via biopsy and managed with ED\&C. One melanoma, Breslow depth $0.95 \mathrm{~mm}$, was diagnosed on the back of a 57-year-old woman. She was treated with wide local excision and sentinel lymph node biopsy at UMHS while pursuing insurance versus
Table 3 Management strategies

\begin{tabular}{ll}
\hline Management & $\begin{array}{l}N(\% \\
\text { patients })\end{array}$ \\
\hline Medical & \\
Topical antimicrobial only & $19(8.3)$ \\
Topical antibiotic & $9(3.9)$ \\
Topical antifungal & $4(1.8)$ \\
Topical antiviral & $2(0.9)$ \\
Topical scabicide & $7(3.1)$ \\
Systemic antimicrobial & $71(31.0)$ \\
Topical steroid only & \\
Combination therapy & $20(8.7)$ \\
Topical antimicrobial and steroid & $7(3.1)$ \\
Topical antimicrobial and systemic & $1(0.4)$ \\
antimicrobial & $1(0.4)$ \\
Topical antimicrobial and retinoid & $1(0.4)$ \\
Systemic antimicrobial and topical steroid \\
Systemic antimicrobial and systemic \\
steroid
\end{tabular}

\section{Other}

Oral antihistamine

Salicylic acid pads

Topical retinoids

Topical imiquimod

Topical lactic acid lotion

$1(0.4)$

Topical bimatoprost

$1(0.4)$

Topical minoxidil

$1(0.4)$

Hydroxychloroquine

$1(0.4)$

Topical pramoxine cream

$1(0.4)$

Procedure

\section{Diagnostic}

Biopsy 38 (16.6)

$\mathrm{KOH}$ 
Table 3 continued

\begin{tabular}{ll}
\hline Management & $\begin{array}{l}\boldsymbol{N}(\% \\
\text { patients })\end{array}$ \\
\hline Therapeutic & \\
Cryotherapy & $44(19.2)$ \\
Intralesional steroid injection & $8(3.5)$ \\
ED\&C & $2(0.9)$ \\
Referral & \\
Referral to plastic surgery & $11(4.8)$ \\
Referral to podiatry & $2(0.9)$ \\
Referral to otolaryngology & $1(0.4)$ \\
Referral to rheumatology & $1(0.4)$ \\
Referral to allergy & $1(0.4)$ \\
Referral to urology & $1(0.4)$ \\
Referral to PMR & $1(0.4)$ \\
\hline
\end{tabular}

$E D \& C$ Electrodessication and curettage, PMR physical medicine and rehabilitation

UMHS charity care. Of the 229 patients, 201 $(87.7 \%)$ received conclusive evaluation and treatment at the time of their initial consultation; ten warranted further dermatologic care in the setting of the UMHS@Hope collaboration; 11 , all with diagnoses such as pilar or epidermoid cysts or other surgical concerns, were referred to plastic surgery for same-day Hope@UMHS excision; and seven patients were referred for further subspecialty treatment and/or surgery that could not be provided at HC.

Patients most commonly received care consistent with New Patient Level 3 evaluation \& management (Table 4). Over the time period evaluated, the clinic was staffed by 92 unique volunteers, who contributed a total of 651 hours (Table 5).

\section{DISCUSSION}

As one of very few free dermatology clinics within the entire state of Michigan, the
Table 4 Services rendered

\begin{tabular}{|c|c|c|}
\hline $\begin{array}{l}\text { CPT } \\
\text { code }\end{array}$ & Level of service & $N$ \\
\hline \multicolumn{3}{|c|}{ Evaluation and management } \\
\hline 99202 & NP Level 2 & 11 \\
\hline 99203 & NP Level 3 & 201 \\
\hline 99204 & NP Level 4 & 2 \\
\hline 99212 & RV Level 2 & 1 \\
\hline 99213 & RV Level 3 & 10 \\
\hline 99214 & RV Level 4 & 3 \\
\hline \multicolumn{3}{|c|}{ Procedures } \\
\hline 11102 & Tangential biopsy of skin & 17 \\
\hline 11103 & Tangential biopsy, each additional lesion & 10 \\
\hline 11104 & Punch biopsy & 21 \\
\hline 11105 & Punch biopsy, each additional lesion & 4 \\
\hline 11200 & Skin tag removal & 3 \\
\hline 17000 & Cryosurgery of premalignant lesions & 20 \\
\hline 17003 & $\begin{array}{l}\text { Cryosurgery of premalignant, each } \\
\text { additional lesion }\end{array}$ & 4 \\
\hline 17110 & $\begin{array}{l}\text { Destruction (Cryo, ED\&C) benign } \\
\text { lesions }\end{array}$ & 17 \\
\hline 17262 & $\mathrm{ED} \& \mathrm{C}$ malignant lesion $1.1-2.0 \mathrm{~cm}$ & 1 \\
\hline 11900 & Intralesional injection & 8 \\
\hline 54056 & Cryosurgery of penis & 10 \\
\hline 87220 & Potassium Hydroxide & 10 \\
\hline
\end{tabular}

$C P T$ Current procedural terminology, $N P$ new patient, $R V$ return visit

Hope@UMHS collaboration patches a gap within Southeast Michigan's health care safety net. Over the course of 8 years, HC referred 294 uninsured patients for dermatology consultation. The no-show rate of $13.4 \%$, lower than the average no-show rates (17-31\%) for dermatology clinics reported in the literature [27], demonstrated that patients were motivated to receive care. The no-show rate is noteworthy when viewed in context of a safety net clinic, as 
Table 5 Volunteer contribution $\log$ for 30 clinics, 2012-2020

\begin{tabular}{clll}
\hline $\begin{array}{l}\text { Volunteer } \\
\text { position }\end{array}$ & $\begin{array}{l}\text { Number of } \\
\text { volunteers }\end{array}$ & $\begin{array}{l}\text { Number } \\
\text { of shifts }\end{array}$ & $\begin{array}{l}\text { Total number of } \\
\text { volunteer hours }\end{array}$ \\
\hline $\begin{array}{c}\text { Attending } \\
\text { physician }\end{array}$ & 13 & 51 & 168 \\
$\begin{array}{c}\text { Physician's } \\
\text { assistant }\end{array}$ & 1 & 2 & 6 \\
$\begin{array}{c}\text { Resident } \\
\text { Medical }\end{array}$ & 45 & 82 & 276 \\
student & 16 & 16 & 48 \\
$\begin{array}{c}\text { MA/LPN } \\
\text { Front desk }\end{array}$ & 5 & 23 & 85.5 \\
staff & 19 & 67.5 \\
Total & 92 & 193 & 651 \\
\hline
\end{tabular}

$L P N$ Licensed practical nurse, $M A$ medical assistant

indigent patients are more than threefold more likely than their commercially insured counterparts to miss an appointment [27]. Of the patients evaluated in the clinic, $87 \%$ received definitive care upon initial consultation. A wide range of diagnoses were made. Nine patients were diagnosed with skin cancer, including one melanoma, and received definitive treatment. Our partnership also facilitated patient followup at Hope Clinic, which allowed the outreach clinic to focus on new consultations and thus treat a greater number of patients. Although not formally measured in our population, patients in clinic often expressed their gratitude for our efforts. Patient perception of the care received at free clinics is resoundingly positive: one survey showed that $97 \%$ of patients are satisfied with the care received at their free clinic, and 95.3\% say they will likely use the clinic again [31].

Providers also benefit from Hope@UMHS efforts. Within the general population, volunteering positively affects mental health [32]. Participating in humanitarian efforts may increase provider satisfaction and decrease burnout by increasing psychological wellness via enhanced morale, social connections, and altruism [33]. Physician volunteers are most commonly motivated by humanitarian and prosocial desires [36], although a formal survey on volunteer satisfaction in our setting would be needed to investigate this further. Our ongoing involvement with Hope@UMHS illustrates the sustainability of volunteerism within our institution.

Involving learners in the care of underserved populations has many advantages. For medical students, volunteering allows for early exposure to dermatology and serves as an excellent clinical teaching tool through bedside learning with residents and faculty. Similarly, residents gain an opportunity to treat a demographically diverse patient population as well as to become aware of the logistical barriers to patient compliance in the underserved as well as the general population. The Accreditation Council for Graduate Medical Education (ACGME) recognizes the importance of diversity in resident training, designating the care of diverse populations (including diversity in socioeconomic status, culture, national origin, and race) as a core competency that residents must fulfill prior to graduation $[37,38]$. Research shows that free clinics may also play an important, formative role in career-long service among learners. Programs that offer opportunities for learners to work with underserved individuals have a positive impact on students' attitudes toward this population and may increase the likelihood for future service-based work [39].

The support of our department and institution was critical for our ability to provide comprehensive care to Hope@UMHS patients. Our affiliation with an academic center provided us with a pool of highly trained dermatologists and ancillary staff to recruit as volunteers. Engagement with legal, risk management, senior administration, and facilities management ensured liability coverage for UMHS volunteers involved in the Hope@UMHS efforts. By utilizing UMHS clinic space, we had access to specialized equipment which allowed providers to render point-of-care services. The ability to offer conclusive evaluation and treatment was of particular importance for this population given the many barriers to patient follow-up. Although not formally measured, the literature also suggests that operating in UMHS facilities 
may have increased volunteer satisfaction, as a survey of physicians at a different safety net clinic found the most commonly cited challenges to be limited supplies and subpar equipment [21].

\section{Limitations}

Management recommendations may not correlate with compliance and patient outcomes, which were not analyzed in this study. Although the longevity of the collaboration suggests a mutually satisfactory arrangement, we also did not formally measure patient or volunteer satisfaction. Because of the clinic schedule, delays occur between referral and evaluation. Referring primary care providers must triage consultations and consider alternative options (emergency department, close primary care physician follow-up) when waiting is not reasonable. While retrospective in design, our results provide direction for future prospective study and analyses.

\section{CONCLUSION}

Our experience illustrates that collaborating with a nonprofit community clinic to provide free, comprehensive dermatology care in a university hospital setting is both feasible and impactful to those providing and receiving care and to the greater community. Future directions for improvement include the addition of teledermatology, including E-consults from healthcare providers, to bridge the gap between clinic sessions, as well as expanding the model to collaborate with other primary care community outreach efforts.

\section{ACKNOWLEDGEMENTS}

Funding. No funding or sponsorship was received for this study or publication of this article. The journal's Rapid Service Fee was funded by the authors.
Authorship. All named authors meet the International Committee of Medical Journal Editors (ICMJE) criteria for authorship for this article, take responsibility for the integrity of the work as a whole, and have given their approval for this version to be published.

Disclosures. Thomas Hester, Reinie Thomas, Jean Cederna, Ann Marie Peterson, Julie Brown, Timothy M Johnson, and Kelly B Cha have nothing to disclose.

Compliance with Ethics Guidelines. The study was considered exempt research by the University of Michigan Institutional Review Board (IRB) (Study eResearch ID: HUM00182333; date of IRB exempt determination: 19 May 2020).

Data Availability. All data generated or analyzed during this study are included in this published article.

Open Access. This article is licensed under a Creative Commons Attribution-NonCommercial 4.0 International License, which permits any non-commercial use, sharing, adaptation, distribution and reproduction in any medium or format, as long as you give appropriate credit to the original author(s) and the source, provide a link to the Creative Commons licence, and indicate if changes were made. The images or other third party material in this article are included in the article's Creative Commons licence, unless indicated otherwise in a credit line to the material. If material is not included in the article's Creative Commons licence and your intended use is not permitted by statutory regulation or exceeds the permitted use, you will need to obtain permission directly from the copyright holder. To view a copy of this licence, visit http://creativecommons.org/licenses/by$\mathrm{nc} / 4.0 /$.

\section{REFERENCES}

1. Dickman SL, Himmelstein DU, Woolhandler S. Inequality and the health-care system in the USA. Lancet. 2017;389(10077):1431-41. 
2. Hoffman C, Paradise J. Health insurance and access to health care in the United States. Ann N Y Acad Sci. 2008;1136:149-60.

3. Freeman JD, Kadiyala S, Bell JF, Martin DP. The causal effect of health insurance on utilization and outcomes in adults: a systematic review of US studies. Med Care. 2008;46(10):1023-32.

4. Halpern MT, Ward EM, Pavluck AL, Schrag NM, Bian J, Chen AY. Association of insurance status and ethnicity with cancer stage at diagnosis for 12 cancer sites: a retrospective analysis. Lancet Oncol. 2008;9(3):222-31.

5. Adashi EY, Geiger HJ, Fine MD. Health care reform and primary care-the growing importance of the community health center. $\mathrm{N}$ Engl J Med. 2010;362(22):2047-50.

6. Darnell JS. Free clinics in the United States: a nationwide survey. Arch Intern Med. 2010;170(11): 946-53.

7. Free Clinics of Michigan. Find a clinic. https:// www.fcomi.org/. 2020. Accessed 20 Aug 2020.

8. Berchick ER, Barnett JC, Upton RD. Current population reports, P60-267(RV). Health insurance coverage in the United States: 2018. US Census Bureau, editor. Washington DC: US Government Printing Office; 2019.

9. Alghothani L, Jacks SK, Vander Horst A, Zirwas MJ. Disparities in access to dermatologic care according to insurance type. Arch Dermatol. 2012;148(8): 956-7.

10. Mulcahy A, Mehrotra A, Edison K, Uscher-Pines L. Variation in dermatologist visits by sociodemographic characteristics. J Am Acad Dermatol. 2017;76(5):918-24.

11. Tripathi R, Knusel KD, Ezaldein HH, Scott JF, Bordeaux JS. Association of demographic and socioeconomic characteristics with differences in use of outpatient dermatology services in the United States. JAMA Dermatol. 2018;154(11):1286-91.

12. Kimball $\mathrm{AB}$, Resneck JS Jr. The US dermatology workforce: a specialty remains in shortage. J Am Acad Dermatol. 2008;59(5):741-5.

13. Suneja T, Smith ED, Chen GJ, Zipperstein KJ, Fleischer AB Jr, Feldman SR. Waiting times to see a dermatologist are perceived as too long by dermatologists: implications for the dermatology workforce. Arch Dermatol. 2001;137(10):1303-7.

14. Resneck JS Jr, Isenstein A, Kimball AB. Few Medicaid and uninsured patients are accessing dermatologists. J Am Acad Dermatol. 2006;55(6):1084-8.
15. Rogers AT, Semenov YR, Kwatra SG, Okoye GA. Racial disparities in the management of acne: evidence from the National Ambulatory Medical Care Survey, 2005-2014. J Dermatolog Treat. 2018;29(3): 287-9.

16. Arakaki RY, Strazzula L, Woo E, Kroshinsky D. The impact of dermatology consultation on diagnostic accuracy and antibiotic use among patients with suspected cellulitis seen at outpatient internal medicine offices: a randomized clinical trial. JAMA Dermatol. 2014;150(10):1056-61.

17. Li DG, Xia FD, Khosravi H, et al. Outcomes of early dermatology consultation for inpatients diagnosed with cellulitis. JAMA Dermatol. 2018;154(5): 537-43.

18. Ko LN, Garza-Mayers AC, St John J, et al. Effect of dermatology consultation on outcomes for patients with presumed cellulitis: a randomized clinical trial. JAMA Dermatol. 2018;154(5):529-36.

19. Aneja S, Aneja S, Bordeaux JS. Association of increased dermatologist density with lower melanoma mortality. Arch Dermatol. 2012;148(2): $174-8$.

20. Pennie ML, Soon SL, Risser JB, Veledar E, Culler SD, Chen SC. Melanoma outcomes for Medicare patients: association of stage and survival with detection by a dermatologist vs a nondermatologist. Arch Dermatol. 2007;143(4):488-94.

21. Amini A, Rusthoven CG, Waxweiler TV, et al. Association of health insurance with outcomes in adults ages 18 to 64 years with melanoma in the United States. J Am Acad Dermatol. 2016;74(2): 309-16.

22. Su C, Nguyen KA, Bai HX, et al. Racial disparity in mycosis fungoides: An analysis of 4495 cases from the US National Cancer Database. J Am Acad Dermatol. 2017;77(3):497-502 e492.

23. Dawes SM, Tsai S, Gittleman H, Barnholtz-Sloan JS, Bordeaux JS. Racial disparities in melanoma survival. J Am Acad Dermatol. 2016;75(5):983-91.

24. Kooistra L, Chiang K, Dawes S, Gittleman H, Barnholtz-Sloan J, Bordeaux J. Racial disparities and insurance status: an epidemiological analysis of Ohio melanoma patients. J Am Acad Dermatol. 2018;78(5):998-1000.

25. Shuman AG, Aliu O, Simpson K, et al. Patching the safety net: establishing a free specialty care clinic in an academic medical center. J Health Care Poor Underserved. 2014;25(4):1810-20.

26. Shuman AG, Kupfer R, Simpson K, et al. Implementation of a novel otolaryngology clinic for 
indigent patients. Laryngoscope. 2013;123(9): 2142-7.

27. Cronin PR, DeCoste L, Kimball AB. A multivariate analysis of dermatology missed appointment predictors. JAMA Dermatol. 2013;149(12):1435-7.

28. Cohen AD, Dreiher J, Vardy DA, Weitzman D. Nonattendance in a dermatology clinic-a large sample analysis. J Eur Acad Dermatol Venereol. 2008;22(10):1178-83.

29. Penneys NS, Glaser DA. The incidence of cancellation and nonattendance at a dermatology clinic. J Am Acad Dermatol. 1999;40(5 Pt 1):714-8.

30. Canizares MJ, Penneys NS. The incidence of nonattendance at an urgent care dermatology clinic. J Am Acad Dermatol. 2002;46(3):457-9.

31. Gertz AM, Frank S, Blixen CE. A survey of patients and providers at free clinics across the United States. J Community Health. 2011;36(1):83-93.

32. Tabassum F, Mohan J, Smith P. Association of volunteering with mental well-being: a lifecourse analysis of a national population-based longitudinal study in the UK. BMJ Open. 2016;6(8):e011327.

33. White AA, Chanoff D. Medical Professionalism and Humanitarian Health Care in the American Age of “-isms." J Racial Ethn Health Disparities. 2020;7(4): 595-7.

34. Campbell C, Campbell D, Krier D, Kuehlthau R, Hilmes T, Stromberger M. Reduction in burnout may be a benefit for short-term medical mission volunteers. Mental Health Religion Culture. 2009;12(7):627-37.

35. Piliavin JA, Siegl E. Health benefits of volunteering in the Wisconsin longitudinal study. J Health Soc Behav. 2007;48(4):450-64.

36. McGeehan L, Takehara MA, Daroszewski E. Physicians' perceptions of volunteer service at safety-net clinics. Perm J. 2017;21:16-003.

37. Accreditation Council for Graduate Medical Education (ACGME). ACGME common program requirements (residency). 2020. https://www. acgme.org/Portals/0/PFAssets/ ProgramRequirements/CPRResidency2020.pdf. Accessed 26 Aug 2020.

38. Buster KJ, Stevens EI, Elmets CA. Dermatologic health disparities. Dermatol Clin. 2012;30(1):53-59, viii.

39. Smith SD, Yoon R, Johnson ML, Natarajan L, Beck E. The effect of involvement in a student-run free clinic project on attitudes toward the underserved and interest in primary care. J Health Care Poor Underserved. 2014;25(2):877-89.

40. O'Toole TP, Hanusa BH, Gibbon JL, Boyles SH. Experiences and attitudes of residents and students influence voluntary service with homeless populations. J Gen Intern Med. 1999;14(4):211-6.

41. Tippets E, Westpheling K. The Health PromotionDisease Prevention Project: effect on medical students' attitudes toward practice in medically underserved areas. Fam Med. 1996;28(7):467-71. 